\title{
Ольга Демиденко
}

кандидатка педагогічних наук, доцентка

Національний технічний університет України

«Київський політехнічний інститут імені Ігоря Сікорського»

Київ, Україна

ORCID 0000-0002-0643-5510

olga.demydenko80@gmail.com

\section{Олександра Бахмут}

здобувачка другого (магістерського) рівня

факультет лінгвістики

Національний технічний університет України

«Київський політехнічний інститут імені Ігоря Сікорського»

Київ, Україна

ORCID 0000-0002-1948-4207

sasha.bakhmut@ukr.net

\section{Валерія Крилова}

здобувачка другого (магістерського) рівня

факультет лінгвістики

Національний технічний університет України

«Київський політехнічний інститут імені Ігоря Сікорського»

Київ, Україна

ORCID 0000-0002-1505-9481

valeriya.kr9878@gmail.com

\section{ЛІНГВОКУЛЬТУРНІ ОСОБЛИВОСТІ ІРЛАНДСЬКОГО СЛЕНГУ ТА ЇХ ЗБЕРЕЖЕННЯ У ПЕРЕКЛАДІ}

\begin{abstract}
Анотація. У статті розглянуто питання теорії лінгвокультурних типажів, яка є одним 3 напрямів мовознавства, що розвивається досить активно. Наголошено, що сучасна лінгвістика містить значний обсяг матеріалів, які стосується культурних концептів і мовної особистості. Лінгвокультурний типаж розглядається як впізнаваний образ представника певної культури, сукупність яких і становить культуру того чи іншого суспільства. Популярним методом, який використовують для визначення лінгвокультурного типажу, $\epsilon$ лінгвокультурний метод. Дослідження ірландських типажів, результати якого стисло представлені у цій статті, проведено на матеріалі кінострічки “The Stag” (в українському перекладі «Парубоцька вечірка по-ірландськи») та твору Патрика МакКейба «Мертва школа». У статті розглянуто проблематику існування такого варіанту англійської мови як гіберно-англійська мова, а також розглянуто функціонування цієї мови у лінгвокультурному контексті, особливо такої гілки, як сленг. Зокрема ірландський сленг це окремий пласт гіберно-англійської мови, який відображає певною мірою рівень культури, освіченості, розвитку суспільства Республіки Ірландія. У праці представлено результати опитування щодо специфіки використання ірландського сленгу, окреслено «нетспік» як окрему форму спілкування. Зазначено, що у текстах сучасних ірландських англомовних письменників виявляється більшість давніх складових ірландського самообразу, які й зараз залишаються актуальними, хоча деякі елементи переосмислюються та зазнають трансформації. Проте ірландці ще й досі репрезентують себе як католицьку націю, схильну до містицизму, надмірної чуттєвості, а також до жорстокості й заангажованості в національні питання.
\end{abstract}

Ключові слова: англійська мова; гіберно-англійська; лінгвокультурні типажі; нетспік; сленг; Республіка Ірландія.

\section{1. ВСТУП}

Постановка проблеми. В умовах постійного розвитку англійської мови одночасно розвиваються також її варіанти по усьому світу. На сьогоднішній день в світі їх існує доволі багато: американська англійська, австралійська англійська, шотландська англійська, 
канадська англійська тощо. Не є винятком також ірландський варіант англійської мови, який сформувався у XVII ст. й отримав назву «гіберно-англійська мова». Згідно даних перепису населення 2012 року 4,3 мільйони ірландців, що проживають у Республіці Ірландія та Сполученому Королівстві, розмовляють гіберно-англійською, а 275 тис. ірландців досі використовують англійську як другу мову.

Дослідження теоретичних та практичних аспектів формування гіберно-англійської мови привернули увагу багатьох сучасних науковців, 3-поміж яких лінгвіст Маркк Філппул (Markku Filppula, 1999), який у підручнику "The grammar of Irish English. Language in Hibernian style" описав історію, будову та особливості гіберно-англійської мови. Ця мова сформувалася шляхом об'єднання двох мов: ірландської та англійської. Зважаючи на активний процес глобалізації, гіберно-англійська мова досі піддається сторонньому впливу: виникають нові слова і вирази, змінюється семантика слів, виникають сленгізми. Саме тому у контексті нашого дослідження особлива увага приділятиметься також й ірландському сленгу як особливому репрезентанту гіберно-англійської мови.

Актуальність дослідження зумовлена підвищенням наукового інтересу до вивчення ірландської лінгвокультури, сленгу та гіберно-англійської мови, що виникла у XVII ст.

Аналіз останніх досліджень і публікацій. У працях зарубіжних та вітчизняних соціолінгвістів розв'язуються важливі теоретичні проблеми вивчення соціальних діалектів в європейській та американській лінгвістиці, висвітлюється питання їхнього походження, всебічного розвитку та функціонування. Продовжуючи традиції багатьох відомих мовознавців XV-XX ст., значний внесок у дослідження соціальних діалектів, зокрема у вивченні різних аспектів їхнього функціонування наприкінці XX - поч. XI ст., внесли такі мовознавці: Берегівська, Бондалєтов, Бугера, Вебер, Горбач, Грабяс, Грабовий, Губачек, Делаплас, Слистратов, Кальве, Колен, Мерль, Ретинська, Ставицька, Флайер, Флекснер, Хаймс та багато інших. Разом із тим і дотепер залишається багато невирішених проблем, пов'язаних 3 соціальними діалектами, їх розвитком та функціонуванням. Вивченням лінгвокультурних типажів на стику лінгвістики i культурології займалися Гумбольдт, Потебня, а також головними представниками цієї галузі лінгвістичного знання вважаються такі відомі лінгвісти, як: Арутюнова, Богданович, Воробйов, Дмітрісва, Карасік, Маслова, Телія, Степанов, Шаклеїн та інші.

Мета статті - висвітлення гіберно-англійської мови у контексті їі сучасної сленгової репрезентації.

\section{2. ТЕОРЕТИЧНЕ ОБГРУНТУВАННЯ}

Термін «лінгвокультурний типаж» був запроваджений для більш повного відображення всього змісту мовної особистості, типізованої в культурологічному аспекті. Різні науковці розглядають цей термін 3 різних позицій. Наприклад, під терміном «лінгвокультурний типаж» ми розуміємо «впізнаваний образ представника певної культури, сукупність яких і становить культуру того чи іншого суспільства» (Карасик \& Дмитриева, 2005). Мовознавець Карасік визначає лінгвокультурний типаж також як різновид концепту, який має понятійну, ціннісну і образну зіставні (Карасик, 2010).

Ірландські лінгвотипажі та їх сленгова репрезентація розглянуто на прикладах 3 художньої літератури.

Сленгізмами $є$ неофіційні слова та терміни для повсякденного вжитку. Хоча деякі сленгові слова можуть заміняти звичайні у такій формі, яку деякі люди вважають образливою або недоречною, більшість сленгізмів не є такими.

\section{3. МЕТОДИ}

Для проведення дослідження застосовано низку загальнонаукових та лінгвістичних методів: описовий метод (використаний для обгрунтування теоретичного матеріалу стосовно гіберно-англійської мови та лінгвокультурології), метод аналізу (для інтерпретації та систематизації відібраного теоретичного матеріалу), дедуктивний метод (використаний при 
переході від загального опису до безпосереднього аналізу явищ), індуктивний метод (від конкретного до загального), соціологічний метод опитування для визначення сучасних особливостей функціонування гіберно-англійської мови.

\section{3. РЕЗУЛЬТАТИ Й ОБГОВОРЕННЯ}

Теорія лінгвокультурних типажів є одним з актуальних напрямків мовознавства, що пов'язаний 3 дослідженнями культурних концептів i мовної особистості. Теорія лінгвокультурних типажів виникла 3 такої науки, як лінгвоперсонологія. Цей напрям лінгвістики також вивчав Лотман (2000). Учений-мовознавець зазначав, що поведінка людини регулюється не тільки законами антропології і загальної психології («поведінка дитини», «поведінка чоловіків, жінок» тощо), але і соціальної семіотики («поведінка селян», «поведінка лицарів») і стилями («благородний», «вульгарний», «низький») (Лотман, 2000).

Термін «лінгвокультурний типаж» був запроваджений для більш повного відображення всього змісту мовної особистості, типізованої в культурологічному аспекті. Різні науковці розглядають цей термін з різних позицій. Наприклад, за Карасіком і Дмітрієвою (Карасик \& Дмитриева, 2005) під терміном «лінгвокультурний типаж» ми розуміємо впізнаваний образ представника певної культури, сукупність яких і становить культуру того чи іншого суспільства. Карасік (Карасик, 2010) визначає лінгвокультурний типаж також як різновид концепту, який має понятійну, ціннісну і образну зіставні.

У свою чергу Дмітрієва (Дмитриева, 2007) вважає, що лінгвокультурний типаж $є$ певною модельною особистістю 3 набором унікальних характеристик, властивих певній культурі, тобто це символ культури всередині культури, і можливо для представників інших національно-культурних спільнот.

Потрібно зазначити, що поняття «лінгвокультурний типаж» можна співвідносити 3 поняттями «модельна особистість», «роль», «стереотип», «амплуа», «персонаж», «імідж», «мовний портрет», при цьому, на думку Ярмахової (2005), відрізняючись від цих понять об'єктивністю, деталізацією (як концепт, типаж включає не тільки поняттєву, а й оцінну та образно-перцептивну складові) і багатомірністю.

Отже, поділяючи думку Карасіка та Дмітрієвої (Карасик \& Дмитриева, 2005), під лінгвокультурним типажем розуміємо впізнаваний образ представника певної культури, сукупність яких і становить культуру того чи іншого суспільства.

Слід згадати, що лінгвокультурний типаж $\epsilon$ особливим типом лінгвокультурних концептів, «найважливіші характеристики якого складаються в типізованості певної особистості, значущості цієї особистості для певної лінгвокультури» (Сукаленко, 2012, c. 101).

Популярним методом, який використовують для визначення лінгвокультурного типажу, $\epsilon$ лінгвокультурний метод. Проте опиратися суто на нього при визначенні лінгвокультурного типажу не варто, адже ще не доведено, що такий метод дійсно існує. За Дмітрієвою (Дмитриева, 2007), лінгвокультурний метод є сукупністю методів, прийомів та технологій визначення зв'язку між культурою, та одиницями мови і мовлення, і включає такі основні методи, як-от:

- синхронний (порівняння лінгвокультурних концептів одного й того самого періоду);

- діахронний (вивчення типових рис та мовленнєвих ознак певного суспільства протягом усього існування);

- історико-генетичний (простеження періоду формування концепту від початку його зародження до сьогоднішніх днів);

- структурний (виокремлення структурних елементів і встановлення зв'язків між ними);

- семантичний (опис семантики компонентів як цілісної структури);

- типологічний (виявлення типологічної схожості між концептами різних культур);

- дискурсивний (вивчення лінгвокультурного типажу в умовах зміни дискурсивних практик).

За Коч (2010), обов'язковими пунктами вивчення та опису лінгвокультурного типажу 
також $\epsilon$ :

1. Етимологічний аналіз ключової номінації концепту;

2. Визначення, наскільки часто така номінація використовується в різних типах дискурсів та дискурсивних практик;

3. Аналіз системних відношень між такою ключовою номінацією та іншими мовними одиницями, які відображають певний типаж;

4. Визначення культурно прецедентних одиниць, які визначають тип особистості, характеризують його / іiі мовленнєві та комунікативні характеристики тощо.

Проте дотепер поза увагою науковців залишається сленгова репрезентація лінгвокультурного типажу.

Потрібно зазначити, що сленг поділяється не тільки на лайку, а й на багато інших відгалужень. Зокрема ірландський сленг - це окремий пласт гіберно-англійської мови, який відображає певною мірою рівень культури, освіченості, розвитку суспільства Республіки Ірландія.

Саме завдяки сленгу викоремилася така форма інтернет-спілкування, як «нетспік». Головною їі особливістю є те, що вона передає і усні, і писемні форми слова. Наприклад, для передачі усних форм використовуються смайли, гіфки (8-бітні рухомі картинки) тощо. Інтернет-сленг є досить розмитим поняттям, так як він активно розвивається та містить багато інших жаргонів, і тому цей феномен на сьогодні не має чіткого визначення й лінгвістичного потрактування. Аудиторія користувачів Інтернету досить масштабна та різноманітна, що унеможливлює кваліфікацію всього загалу Інтернет-сленгової лексики як різновиду суто молодіжного сленгу. Як один із шарів молодіжного сленгу варто розглядати тільки частину Інтернет-сленгу, оскільки основними користувачами мережі є молодь. Якщо брати до уваги вікові групи інтернет-користувачів таких країн, як Великобританія, США, Німеччина, Україна та Росія, можна зробити висновок, що найактивнішою групою користувачів Інтернету є молоді люди віком до 25 років.

Однією 3 найхарактерніших ознак молодіжних Інтернет-сленгізмів англійської, німецької, російської та української мов постає скорочення слів. Широке використання такого способу формування нових сленгізмів зумовлене необхідністю прискорення та спрощення процесу набору тексту задля максимально швидшого обміну смс або Інтернет повідомленнями та задля наближення цього виду комунікації до прямого (усного)спілкування. Для передачі писемної форми використовується сам текст. Також нормальним $€$ використання скорочень, наприклад: yolo = "you live only once", lol = "laughing out loud", brb= 'be right back', tnx, thx, thanx = thanks «дякую», rly = really «правда», PLZ, PLS = please "будь ласка»; нім.: gg = gegen «напроти», еig = eigentlich «насправді»; укр.: прив «привіт», Інет «Інтернет», дяки «дякую»; рос.: спс = спасибо «дякую», чз = через «через / шляхом», лю = люблю «люблю».

Цікавим є те, що російській молодіжний Інтернет-сленг створює нові абревіації через неправильну розкладку клавіатури. Написання деяких англійських абревіатур на російській розкладці клавіатури сприяло виникненню нових слів: рос. ЗЫ, ЗЫЖ еквівалент $P$. S. (PS або PS: від лат. Post Scriptum, «після підпису») - логічне доповнення до основного тексту.

Отже, основна частина сленгізмів, що потрапили до молодіжної мови через мережу, $\epsilon$ скорочення. Унаслідок домінування англійської 3-поміж контент-мов Інтернет-сайтів у німецькому, російському та українському молодіжному Інтернет-слензі спостерігаємо приріст запозичень з англійської мови або успадкування словотвірних процесів рідної мови. Але німецько-, російсько- та україномовна молодь прагне вирізнитись по-своєму, тому створює власні оригінальні скорочення.

Розглядаючи та аналізуючи ірландську культуру, потрібно зазначити, що існують безліч медіа текстів, де описують буття, характер, традиції, звички, тобто містять в собі все, що допоможе глядачу зрозуміти, хто такий ірландець та чим він різниться від інших представників інших лінгвокультур.

Одним із яскравих лінгвокультурних типажів Ірландії $є$ ірландець Педді. Це - збірний 
образ народу Ірландії, який уособлює не найкращі його риси. Наприклад, Педді - це типовий ірландський п'яничка, який нічого не досягнув у цьому житті і нічого не намагається робити, але при цьому в ньому живе бунтарський дух (De Nie, 2004, p. 12). Потрібно також зазначити, що ім'я «Педді» - це пестливе скорочення від імені «Патрік», яке є дуже поширеним у Республіці Ірландія. Такий образ був сформований на основі протистояння 3 Великою Британією, яка через історичне підгрунтя досі веде моральну війну з Республікою Ірландія.

Наразі яскравим представником ірландських лінгвокультурних типажів $\epsilon$ лінгвокультурний типаж під назвою «Ірландський емігрант», який був описаний та досліджений Лушніковою та Старцевою (Лушникова \& Старцева, 2012). Така назва пов'язана 3 тим, що ірландці з часом почали іммігрувати за кордон Республіки Ірландія, і їм вдалося змінити ставлення людей до них: замість таких асоціацій, як «гульвіса», «п'яничка» та «ледар», люди почали асоціювати їх з добрими та комунікативними представниками своєї нації.

Ірландці нерідко розглядаються як дещо брутальна нація. Заради доказу цього стереотипу нами було проведено опитування під назвою "Usage of Irish slang", яке проводилося 3 метою визначення, наскільки відображаються стереотипи про ірландців і їх національний характер у ірландському сленгу. В опитуванні взяло участь 760 респондентів різного віку на добровільній основі, які відгукнулися на повідомлення в соціальній мережі Фейсбук. Опитування охоплювало шість основних запитань:

1. «Ви говорите загальноприйнятою англійською чи ірландською англійською?»

2. «Як часто ви чуєте сленг у повсякденному житті?»

3. «Від кого ви чуєте сленгові лексику?»

4. «Ви використовуєте сленг у мовленні?»

5. «Ви використовуєте лайки у мовленні?»

6. «У яких умовах ви використовуєте сленг і лайки?»

На основі результатів опитування було зроблено такі висновки:

1) не зважаючи на те, що наразі стверджується, що британська англійська $\epsilon$ домінуючою мовою на території Республіки Ірландія, голоси респондентів розділилися - на питання «Якою мовою ви розмовляєте: британською чи ірландською англійською?» було дано однаковий процент відповідей на обидва варіанти:

\section{Do you speak Received Pronunciation (English) or Irish English?}
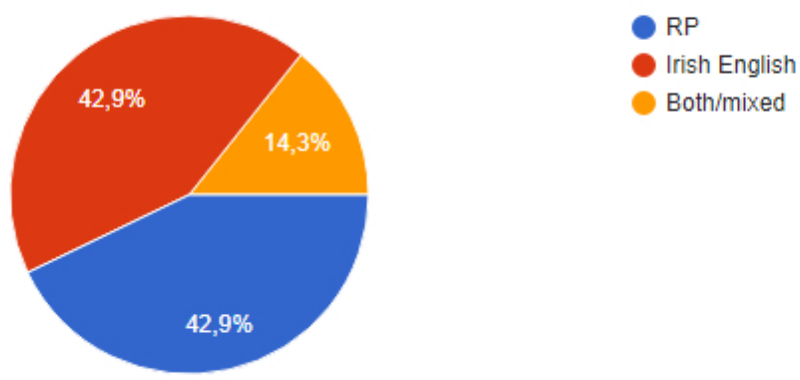

Рис. 1. Розподіл відповідей на запитання «Ви говорите загальноприйнятою англійською чи ірландською англійською?»

2) було виявлено, що сленг є доволі поширеним серед жителів Республіки Ірландія, адже вони чують його кожного дня у повсякденному житті: 
How often do you hear slang in everyday life?

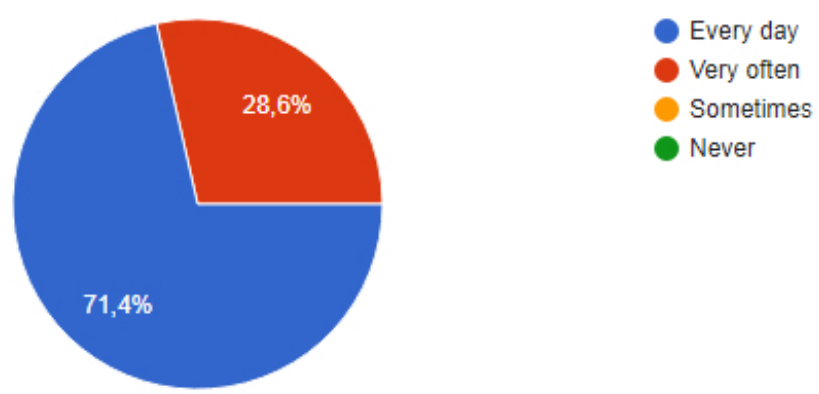

Рис. 2. Розподіл відповідей на запитання «Як часто ви чуєте сленг у повсякденному житті?»

3) як показало дослідження, сленг використовують усі пласти населення. Це не є дивним, адже наразі старше покоління хочу бути ближчим до молодшого, тому вони активно вивчають всі інновації, що є характерними для молодого покоління, та запроваджують їх у власне життя.

4) невід’ємною частиною сленгу є лайка - усі респонденти відповіли, що інколи вони іiі використовують:

\section{Do you use swears/bad words?}

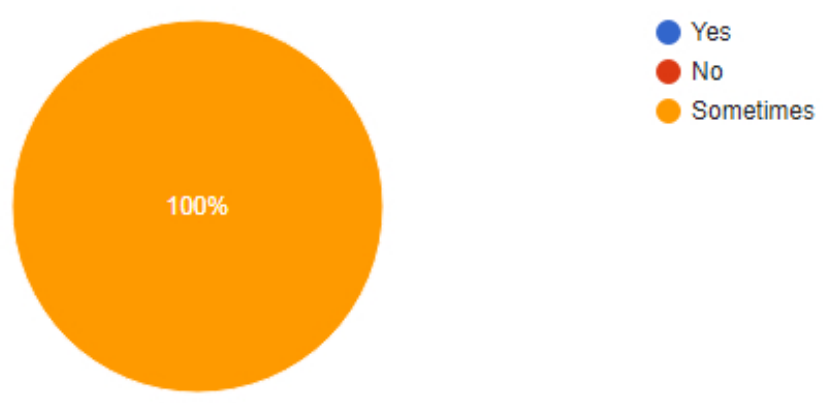

Рис. 3. Розподіл відповідей на запитання «Ви використовуєте лайки у мовленні?»

5) ірландці використовують сленг тоді, коли:

- вони знаходяться під впливом емоцій;

- спілкуються $з$ друзями;

- у жартах;

- у будь-якій життєвій ситуації;

6) найпопулярнішими сленговими словами, серед яких $є$ також обсентна лексика, виявилися такі лексичні одиниці:

1. The word "fuck" is used to express anger, disgust, peremptory rejection, etc., often followed by a pronoun, as 'you' or 'it' (dictionary.com);

2. "Bastard" is "a vicious, despicable, or thoroughly disliked person" (dictionary.com);

3. "Taking the piss" means "to say something to try to make someone look silly" 
(macmillandictionary.com);

4. "Bloke" means "man; fellow; guy" (dictionary.com);

5. "Bollox" is slightly affectionate term of abuse (urbandictionary.com);

5. "Dickhead" means "a stupid man" (macmillandictionary.com);

6. "Bitch" is an insulting word for 'a woman' (macmillandictionary.com);

7. "Shit" is used as something that you do not like or think is of very bad quality (macmillandictionary.com);

8. "Bugger" is "a fellow or lad (used affectionately or abusively)" (dictionary.com).

Повертаючись до сучасних ірландських лінгвокультурних типажів, розглянемо стрічку “The Stag” або ж в перекладі українською «Парубоцька вечірка по-ірландськи» - дебютна кінокомедія режисера Джона Батлера, що вийшла у 2013 році.

Стереотипність ірландського образу відображається та прослідковується дуже чітко протягом всього фільму. Зневажливий спосіб життя, схильність до вживання алкоголю, безтурботність, байдуже відношення до серйозних стосунків, - всі ці якості неодноразово висвітлюються в сюжеті та підкреслюються задля того, щоб передати сутність та пріоритети ірландської молоді: байдужість до створення сім’ї та нехтування здоровим способом життя. Наприклад:

- You are going to end up on your own, alone forever. Don't you want to find someone to love?

- Jesus, Fionan, who are you, my f*cking mother? When I find someone, I'll let you know.

- Okay. How's the wedding plans going?

- Do you really want to know?

- Yeah. I'd like to talk about it. Still a bit stressed?

- Each detail leads to the next detail and each decision is important. It's exhausting...(байдужість до створення сім'і) ("The Stag” film script).

Виокремлюється тема нерозсудливості та необережності ірландців щодо свого життя та безпеки під час вечірок або посиденьок в пабі, без чого ірландець не може обійтись протягом свого довгоочікуваного вихідного дня чи відпустки. Наприклад:

- He's making his own way down.

- Okay. He's making his own way down.

- Have fun!

- Okay, you too!

- Bye.

- Bye, have fun. Bye.

- Bye!

- Let's go and do our way down before you got married!(нехтування безпекою та способом життя) (“The Stag” film script).

Схильність ірландців до вживання алкоголю окреслюється в найяскравіших фарбах. Стереотип ірландців, як народу, що любить випити та відпочити за чарочкою пива, займає найголовнішу роль серед усіх інших, перерахованих вище. Прикладом $є$ наступні строки:

- We were just on our way to bed before you arrived.

- We've a long day of walking tomorrow.

- Walking whence? From pub to pub?

- My money, all of my money...

- I don't have any money.

- Oh...

- Oh, my God.

- Isn't that insane?

- Do you want a beaker of whisky?

- I do.

- You do. Of course you do.

- Just go out and join the lads.

- All right. 
- Coming. ("The Stag” film script).

Стосовно ірландської літератури, розглянемо твір Патрика МакКейба (McCabe, 2002). Він відомий сучасний ірландський письменник-романіст. Його роман «Мертва школа» (1995) цікавий тим, що у центрі оповіді перебуває конфлікт між двома персонажами Рафаелем Беллом і Мелакі Дадженом, які світоглядно і поколіннєво відображають зіткнення двох різних моделей сприйняття Ірландії.

Розглянемо образ традиційної Ірландії, якою вона запам'яталася Рафаелю Беллу з його дитинства. На першому плані постає відомий ірландський самообраз селянської, католицької країни, а також не менш відомий образ Ірландії як острівної держави, відмежованої від решти світу. "An action time - once upon a time in Ireland, and we are in a quiet village, where nothing special has happened for about a hundred years and may never happen. But no one really cares. People are extremely happy with the way they live, working hard in the fields, praying in the evening and behaving well for the sake of the Lord, who looks down on all from his heights" (McCabe, 2002, p. 34). Сентиментально-містичний ірландців можна простежити на прикладі опису сімейної ідилії з дитинства Рафаеля: “They were sitting together, drinking tea, only mother and Raphael, and the Virgin Mary on the windowsill, smiling at them and saying, "I am proud of this happy and blessed family” (McCabe, 2002, p. 39). Світ дитинства Рафаеля наповнений затишком, гармонією, ідеальним порядком. Втрату цієї Ірландії, відомої 3 дитинства, Рафаель Белл не зможе пережити на схилі літ.

Ірландія 1960-х pp. - часів дитинства Мелакі Даджена - хоча й позначена певними ідилічними рисами, все ж постає трохи інакшою. По-перше, перед нами не глуха сільська місцевість, а маленьке містечко, яке все ще зберігає певні національні традиції. По-друге, образ щасливого дитинства Мелакі навіть далеко не нагадує того селянського містичночуттєвого світу, в якому зростав Рафаель. Із дитячих років Мелакі запам'ятав недільні відвідини церкви з батьком, чоловічі посиденьки в готелі за кухлем пива і радісне повернення додому, де на них чекала мати з приготовленим сніданком (McCabe, 2002). Слід зазначити, що питущих ірландців та все, що пов'язане з випивкою, широко розтиражоване і в сучасному суспільстві.

\section{4. ВИСНОВКИ І НАПРЯМИ ПОДАЛЬШИХ ДОСЛІДЖЕНЬ}

У процесі дослідження 3'ясовано, що термін «лінгвокультурний типаж» був запроваджений для повного відображення всього змісту мовної особистості, типізованої в культурологічному аспекті. Лінгвокультурний типаж - впізнаваний образ представника певної культури, сукупність яких і становить культуру того чи іншого суспільства. Варто відзначити, що лінгвокультурний типаж характеризується подвійною природою: 3 одного боку, він являє собою концепт, з іншого боку - мовну особистість, а також є різновидом концептів в тому плані, що представляє собою квант знання про типового представника суспільства.

В основі формування етнічної свідомості і культури у якості регуляторів поведінки людини лежать як вродженні, так і набуті в процесі соціалізації фактори - культурні стереотипи, які засвоюються з того моменту, як тільки людина починає ідентифікувати себе 3 певним етносом, певною культурою і усвідомлювати себе їх елементом. Механізмом формування стереотипів $є$ багато когнітивних процесів, тому що стереотипи виконують ряд когнітивних функцій - функцію схематизації і спрощення, функцію формування і збереження групової ідеології тощо.

Стереотипізація проявляється здебільшого на лексичному та синтаксичному рівнях мови, оскільки чим вищий рівень, тим більше смислове навантаження він має. Таким чином, найбільшого ефекту досягають ті стереотипи, які представлені і закріплені у текстах, тобто на рівні дискурсу. Ірландський гумористичний дискурс, наприклад, вміщує в собі чи не всі існуючі стереотипи щодо Ірландії та іiі мешканців, тим самим пропонуючи дослідникам широке поле для вивчення національних особливостей цього народу.

Відображаючи ірландські лінгвокультурні типажі у медіа текстах та аналізуючи 
приклади 3 відомих стрічок про дух ірландського народу, можна стверджувати, що стереотипність, яку описує автор в різних ситуаціях та сферах життя, відповідає всім загальноприйнятим судженням щодо жителів зеленого острову. Вони безтурботні люди, які по-своєму сприймають життя на насолоджуються ним так, як вважають за потрібне. Їм байдуже до думки оточуючих, вони знають ціну дружбі, але не дуже поспішають влаштовувати сімейне гніздечко. Схильність ірландців до вживання алкоголю окреслюється в найяскравіших фарбах. Стереотип ірландців як народу, який любить випити та відпочити за чарочкою пива, займає найголовнішу роль серед усіх інших. Проживати момент і не думати про майбутнє - кредо ірландської молоді, з яким вони йдуть протягом всього свого існування та ні трохи не жалкують про свій вибір.

У текстах сучасних ірландських англомовних письменників виявляється більшість давніх складових ірландського самообразу, які й зараз залишаються актуальними, хоча деякі елементи переосмислюються та зазнають трансформації. Проте ірландці ще й досі репрезентують себе як католицьку націю, схильну до містицизму, надмірної чуттєвості, а також до жорстокості й заангажованості в національні питання.

Окрім цього, було проведено опитування під назвою “Usage of Irish slang” $з$ метою визначення, наскільки відображаються стереотипи про ірландців та їхній національний характер у ірландському сленгу. Також було розглянуто питання існування сленгу в гіберноанглійській мові, завдяки чому було класифіковано ознаки, за якими він поділяється. Також було виявлено, що завдяки сленгу виокремилася нова форма спілкування - «нетспік», що поєднує у собі і усні, і писемні форми комунікації.

Перспективним напрямом подальших наукових досліджень вважаємо поглиблене вивчення й аналіз ірландських лігвокульурних типажів, різницю між гіберно-англійською й англійською мовами та культурно-історичними факторами, які роз'єднують ірландське i британське суспільство, а також особливостей перекладу гіберно-англійської мови.

\section{СПИСОК ЛІТЕРАТУРИ}

Дмитриева, О. А. (2007). Лингвокультурные типажи России и Франции ХІХ века. Волгоград: Перемена.

Карасик, В. И., \& Дмитриева, О. А. (2005). Лингвокультурный типаж: к определению понятия. Аксиологическая лингвистика: Лингвокультурные типажи: сб. науч. тр, 5-25. Волгоград: Парадигма.

Карасик, В. И. (2010). Языковая кристаллизащия смысла. Волгоград: Парадигма.

Коч, Н. В. (2010) Исследование концептов в диахронии как теоретическая и методическая проблема. Наукові записки Кіровоградського державного педагогічного університету імені Володимира Винниченка, 89, 316-320.

Лотман, Ю. М. (2000). Семиосфера. СПб.: Искусство-СПб.

Лушникова, Г. И., \& Старцева, Т. В. (2012). Структурные особенности лингвокультурного типажа «Ирландский эмигрант». Вестник КемГУКИ, 18, 145-152.

Сукаленко, Т. М. (2012). До проблеми вивчення лінгвокультурних типажів як концептів. Наукові праці Кам'янець-Подільського національного університету імені Івана Огієнка. Філологічні науки, 29(1), 99103.

Хомяков, В. А. (1971). Введение в изучение сленга - основного компонента английского просторечия. Вологда: ВГПИ.

Ярмахова, Е. А. (2005). Лингвокультурный типаж «английский чудак». Волгоград.

“The Stag” film script. (n. d.). Retrieved October 2, 2020 from https://www.scripts.com/script/the stag 21375

De Nie, M. (2004). The Eternal Paddy: Irish Identity and the British Press. Wisconsin Press.

Filppula, M. (1999). The grammar of Irish English. Language in Hibernian style. New York: Routledge.

Longman Dictionary of Contemporary English. (n. d.) Retrieved October 12, 2020 from https://www.ldoceonline.com/

McCabe, P. (2002). The Dead School. London: Mcmillan.

\section{REFERENCES}

De Nie, M. (2004). The Eternal Paddy: Irish Identity and the British Press. Wisconsin Press.

Dmitriyeva, O. (2007) Lingvokul'turnyye tipazhi Rossii i Frantsii XIX veka [Russian and French inguocultural types of the $X I X$ century]. Volgograd: Peremena. [in Russian]

Karasik, V., \& Dmitriyeva, O. (2005). Lingvokul'turnyy tipazh: $k$ opredeleniyu ponyatiya. Aksiologicheskiye issledovaniya: Tipy angliyskogo yazyka: sb. nauch. tr. [Linguocultural type: definition. Axiological researches: Types of the English language: collected scientific writings]. Volgograd: Paradigma. [in Russian]

Karasik, V. (2010) Yazykovaya kristallizatsiya smysla [Language crystallization of sense]. Volgograd: Paradigma. [in 
Russian]

Khomyakov, V. A. (1971) Vvedeniye v izucheniye slenga - osnovnogo komponenta angliyskogo prostorechiya [Introduction to sleng study - the main component of English common parlance]. Vologda: VGPI. [in Russian]

Koch, N. V. (2010). Issledovaniye kontseptov v diakhronii kak teoreticheskaya i metodicheskaya problema [Concept research in diachrony as theoretical and methodological problem]. Naukovi zapysky Kirovohrads'koho derzhavnoho pedahohichnoho universytetu imeni Volodymyra Vynnychenka, 89, 316-320. [in Russian]

Longman Dictionary of Contemporary English. (n. d.) Retrieved October 12, 2020 from https://www.ldoceonline.com/ [in Russian]

Lotman, Yu. M. (2000). Semiosfera [Semiosphere]. SPb.: Art-SPb. [in Russian]

Lushnikova G. I., \& Startseva T. V. (2012). Strukturnyye osobennosti lingvokul'turnogo tipazha "Irlandskiy emigrant" [Structural peculiarities of lingua-cultural type "Irish emigrant"]. Vestnik KemGUKI, 18, 145-152. [in Russian]

McCabe, P. (2002). The Dead School. London: Mcmillan.

Sukalenko, T. M. (2012). Do problemy vyvchennya linhvokul'turnykh typazhiv yak kontseptiv [To the problem of study of linguocultural types as concepts]. Naukovi pratsi Kam'yanets'-Podil's'koho natsional'noho universytetu imeni Ivana Ohiyenka. Filolohichni nauky, 29(1), 99-103. [in Ukrainian]

“The Stag” film script. (n. d.). Retrieved October 2, 2020 from https://www.scripts.com/script/the stag_21375

Yarmakhova, E. (2005). Lingvokul'turnyy tipazh "angliyskiy chudak" [Linguocultural type "English weirdo"]. Volgograd. [in Russian]

Olga Demydenko, Oleksandra Bakhmut, Valeriia Krylova. Linguocultural features of Irish slang and their presentation in translation. The article presents the results of the linguocultural theory that is one of the most actively developing areas of linguistics. It is caused by the fact that modern linguistics contains a significant amount of material concerning cultural concepts and linguistic personality. The notion of linguistic and cultural type is considered a recognizable image of a particular culture's representative, the totality of which is the culture of a society. The study is based on an analysis of the Irish linguistic and cultural types of the famous film "The Stag" - the debut film comedy directed by John Butler, as well as the novel of Patrick McCabe - "A Dead School". At the heart of the story is a conflict between two characters, Raphael Bell and Melaki Dagen, who, in a worldview and generational way, reflect the clash of two different models of Ireland perception. The study found that the self-esteem of Irish drinkers and everything related to drinking is widely circulated in modern society. Therefore, the topic of drinking, and often even alcoholism, is perceived as specifically Irish. Particular attention was paid to the existence of slang in the Hiberno-English language. The survey called "Usage of Irish slang" was conducted and analyzed. The survey involved 76 respondents of all ages who replied to messages on the social network Facebook. It was also found that due to slang, a completely new form of communication emerged - netspeak, which combines both oral and written forms of communication. Based on the survey and experiment mentioned earlier, there were managed different types of slang: general slang and special slang.

Keywords: English; Hiberno-English; linguocultural types; netspeak; Republic of Ireland; slang. 